\title{
ANALISIS RISIKO PROFILE TERHADAP TINGKAT KESEHATAN BANK SYARI'AH DI INDONESIA (STUDI KASUS BANK MUAMALAT INDONESIA)
}

\author{
Hayanuddin Safri \\ Dosen Tetap Sekolah Tinggi Ilmu Ekonomi Labuhan Batu, Sumatera Utara \\ Email: hayanuddinhrp@gmail.com
}

\begin{abstract}
Abstrak
Penilaian tingkat kesehatan didasarkan pada Risiko-Risiko Bank dan dampak yang ditimbulkan pada kinerja Bank secara keseluruhan. Hal ini dilakukan dengan cara mengidentifikasi faktor internal maupun eksternal yang dapat meningkatkan Risiko atau mempengaruhi kinerja keuangan Bank pada saat ini dan di masa yang akan datang. Dengan demikian, Bank diharapkan mampu mendeteksi secara lebih dini akar permasalahan Bank serta mengambil langkah-langkah pencegahan dan perbaikan secara efektif dan efisien. Penelitian ini bertujuan untuk menguji dan menganalisis Penilaian tingkat kesehatan Bank Syari'ah, berdasarkan Peraturan OJK No.8/ POJK.03 Tahun 2014 terhadap Bank Muaamalat Indonesia. Variabel Bebas dalam artikel ini meliputi; Risiko Kredit $\left(\mathrm{X}_{1}\right)$, Risiko Pasar $\left(\mathrm{X}_{2}\right)$, Risiko Operasional $\left(\mathrm{X}_{3}\right)$, Risiko Likuiditas $\left(\mathrm{X}_{4}\right)$, Risiko Hukum $\left(\mathrm{X}_{5}\right)$, Risiko Stratejik $\left(\mathrm{X}_{6}\right)$, Risiko Kepatuhan $\left(\mathrm{X}_{7}\right)$, Risiko Reputasi $\left(\mathrm{X}_{8}\right)$, Risiko Imbal Hasil $\left(\mathrm{X}_{9}\right)$ dan Risiko Investasi $\left(\mathrm{X}_{10}\right)$ dan Variabel Terikat yaitu Tingkat kesehatan bank (Y) Bank Muamalat Indonesia.
\end{abstract}

Key words: Risiko Profile, Tingkat Kesehatan Bank Syari’ah (BMI)

\section{A. Pendahuluan.}

Bisnis bank adalah bisnis yang sarat dengan risiko sistemik dan massif. Ketika salah satu bank mengalami kebangkrutan, hal ini dapat mempengaruhi bank lain. Krisis perbankan pada pertengahan 1997, misalnya memunculkan berbagai masalah yang begitu kompleks sehingga dengan cepat berubah menjadi krisis ekonomi, krisis sosial, budaya, krisis politik, dan krisis multidimensi. Lembaga perbankan Indonesia pernah merasakan hilangnya kepercayaan publik terhadap bank. Orang merasa ragu untuk menyimpan uang mereka di bank dan menarik uang mereka yang disimpan di bank. Oleh sebab itu kepercayaan publik dapat dibangun dengan bentuk transparansi lembaga perbankan dalam hal laporan keuangan dan kondisi kesehatan bank yang dipublikasikan.

\section{B. Penelitian Terdahulu.}

According to Titin Ruliana, Rina Masyitoh Hariyadi, Siti Winarsih, University of August 17th, 1945 Samarinda, East Kalimantan, Indonesia, Management, Economic Engineering in Agriculture and Rural Development Vol. 16, Issue 1, 2011, in Article "Health Level Of Bank Using Risk Based Bank Rating Conclusions: Based on the results of research and analysis has been done, the researchers can conclude the following: 1) Health assessment of bank using nonperforming loans shows there is bank with a ratio value of the category of "unhealthy" in 2013 and one bank with a ratio value of the category of "unhealthy" in 2014. 2) Health assessment of bank using loan to deposit ratio shows that there are two banks with a ratio value of less healthy in 2012 and the first commercial bank to value ratio is not healthy in 2013 and 2014. 3) Health assessment of bank using Good Corporate Governance (GCG) shows there is one bank with a 
ratio value of the category of "not good" that one bank in 2012, one bank in 2013 and one bank in 2014. 4) Health assessment of bank using Return on Assets shows that there are two banks with less healthy category and one commercial banks with unhealthy category in 2012. In 2013 there is one category of banks with less healthy and one commercial bank in the unhealthy category. In 2014 there were four banks with less healthy category and one commercial banks with unhealthy category. 5) Health assessment of bank using Net Interest Margin indicates that there are one commercial banks with unhealthy category in 2014,6) Health assessment of bank using Capital Adequacy Ratio shows that no bank in the "less healthy" or "unhealthy".

Risk Profile Indicators and Spanish Banks 'Probability of Default from a Regulatory Approach Pilar Gómez-Fernández-Aguado, Purificación Parrado-Martínez and Antonio PartalUreña epartment of Financial Economics and Accounting, University of Jaén, 23071 Jaén, Spain;pigomez@ujaen.es, Published: 19 April 2018. Conclusions: Given the importance of stress exercises as an element of analysis and a policy tool, the EU started to use a new model, called SYMBOL, to measure the quantitative impact of different European Commission proposals. The model can also be used to determine the probability of bank default under the Basel regulatory approach. Our work extends the previous research on the determinants of bank risk, analysing the relationships between the risk indicators proposed by the EBA and the individual default probabilities of Spanish credit institutions during the period of 2008-2016, based on a new measure supported by banking regulation.Our results for Spanish banking credit institutions reveal that capital adequacy, liquidity and asset quality are the main determinants of the banks' probability of default from a regulatory approach.The macroeconomic scenario appears to be significant as well.

\section{Rumusan Masalah.}

1. Apakah Risiko Kredit $\left(\mathrm{X}_{1}\right)$, Risiko Pasar $\left(\mathrm{X}_{2}\right)$, Risiko Operasional $\left(\mathrm{X}_{3}\right)$, Risiko Liquiditas $\left(\mathrm{X}_{4}\right)$, Risiko Hukum $\left(\mathrm{X}_{5}\right)$, Risiko Stratejik $\left(\mathrm{X}_{6}\right)$, Risiko Kepatuhan $\left(\mathrm{X}_{7}\right)$, Risiko Reputasi $\left(\mathrm{X}_{8}\right)$, Risiko Imbal Hasil $\left(\mathrm{X}_{9}\right)$ dan Risiko Investasi $\left(\mathrm{X}_{10}\right)$ secara Parsial mempunyai hubungan yang positif dan signifikan terhadap Tingkat kesehatan bank (Y) Bank Muamalat Indonesia.

2. Apakah Risiko Kredit $\left(\mathrm{X}_{1}\right)$, Risiko Pasar $\left(\mathrm{X}_{2}\right)$, Risiko Operasional $\left(\mathrm{X}_{3}\right)$, Risiko Liquiditas $\left(\mathrm{X}_{4}\right)$, Risiko Hukum $\left(\mathrm{X}_{5}\right)$, Risiko Stratejik $\left(\mathrm{X}_{6}\right)$, Risiko Kepatuhan $\left(\mathrm{X}_{7}\right)$, Risiko Reputasi $\left(\mathrm{X}_{8}\right)$, Risiko Imbal Hasil $\left(\mathrm{X}_{9}\right)$ dan Risiko Investasi $\left(\mathrm{X}_{10}\right)$ secara Simultan mempunyai hubungan yang positif dan signifikan terhadap Tingkat kesehatan bank (Y) Bank Muamalat Indonesia.

\section{Hipotesis.}

1. Adanya Hubungan yang positif dan Signifikan secara Parsial antara variabel Risiko Kredit $\left(\mathrm{X}_{1}\right)$, Risiko Pasar $\left(\mathrm{X}_{2}\right)$, Risiko Operasional $\left(\mathrm{X}_{3}\right)$, Risiko Liquiditas $\left(\mathrm{X}_{4}\right)$, Risiko Hukum $\left(\mathrm{X}_{5}\right)$, Risiko Stratejik $\left(\mathrm{X}_{6}\right)$, Risiko Kepatuhan $\left(\mathrm{X}_{7}\right)$, Risiko Reputasi $\left(\mathrm{X}_{8}\right)$, Risiko Imbal Hasil $\left(\mathrm{X}_{9}\right)$ dan Risiko Investasi $\left(\mathrm{X}_{10}\right)$ secara Parsial mempunyai hubungan yang positif dan signifikan terhadap Tingkat kesehatan bank (Y) Bank Muamalat Indonesia.

2. Adanya Hubungan yang positif dan Signifikan secara Simultan variabel Risiko Kredit $\left(\mathrm{X}_{1}\right)$, Risiko Pasar $\left(\mathrm{X}_{2}\right)$, Risiko Operasional $\left(\mathrm{X}_{3}\right)$, Risiko Liquiditas $\left(\mathrm{X}_{4}\right)$, Risiko Hukum $\left(\mathrm{X}_{5}\right)$, Risiko Stratejik $\left(\mathrm{X}_{6}\right)$, Risiko Kepatuhan $\left(\mathrm{X}_{7}\right)$, Risiko Reputasi $\left(\mathrm{X}_{8}\right)$, Risiko Imbal Hasil ( $\left.\mathrm{X}_{9}\right)$ dan Risiko Investasi $\left(\mathrm{X}_{10}\right)$ secara Simultan mempunyai hubungan yang positif dan signifikan terhadap Tingkat kesehatan bank (Y) Bank Muamalat Indonesia. 


\section{E. Landasan Teori. \\ 1) Credit Risk.}

Risiko Kredit adalah Risiko akibat kegagalan debitur dan/atau pihak lain dalam memenuhi kewajiban kepada Bank. Risiko kredit pada umumnya terdapat pada seluruh aktivitas Bank yang kinerjanya bergantung pada kinerja pihak lawan (counterparty), penerbit (issuer), atau kinerja peminjam ana (borrower). Risiko Kredit juga dapat diakibatkan oleh terkonsentrasinya penyediaan dana pada debitur, wilayah geografis, produk, jenis pembiayaan, atau lapangan usaha tertentu. Risiko ini lazim disebut risiko konsentrasi kredit dan wajib diperhitungkan pula dalam penilaian risiko inheren.

\section{a) NPL (Non Performing Loan).}

NPL is the ratio between non-performing loans to total loans. Predicate Health of Bank under the NPL (Bank Indonesia Circular Letter No. 6/23 /DPNP), namely:

(1) NPL <2\%; Very Healthy; (2) $2 \%<\mathrm{NPL} \leq 5 \%$; Healthy; (3) $5 \%<\mathrm{NPL} \leq 8 \%$, Healthy enough; (4) $8 \%<\mathrm{NPL} \leq 12 \%$, Less Healthy; (5) NPL $>12 \%$; Unhealthy.

\section{b) LDR (Loan to Deposit Ratio).}

LDR is the financial ratio of the banking company's that relate to aspects liquidity by comparing the entire amount of credit given to third-party funds. Predicate Health of Bank based LDR Bank (Bank Indonesia Circular Letter No.13/30/DPNP/2011), namely:

(1) LDR $\leq 75 \%$; Very Healthy; (2) $75 \%<$ LDR $\leq 85 \%$; Healthy; (3) $85 \%<$ LDR $\leq 100 \%$; Healthy enough; (4) $100 \%<\mathrm{LDR} \leq 120 \%$, Less Healthy; (5) LDR $>120 \%$; Unhealthy.

\section{2) Market Risk.}

Risiko Pasar adalah Risiko pada posisi neraca dan rekening administratif termasuk transaksi derivatif, akibat perubahan dari kondisi pasar, termasuk risiko perubahan harga option. risiko pasar meliputi antara lain risiko suku bunga, risiko nilai tukar, risiko ekuitas, dan risiko komoditas. risiko suku bunga dapat berasal baik dari posisi trading book maupun posisi banking book. Penerapan manajemen risiko untuk risiko ekuitas dan komoditas wajib diterapkan oleh bank yang melakukan konsolidasi dengan anak perusahaan.

\section{3) Liquidity Risk.}

Risiko Likuiditas adalah Risiko akibat ketidakmampuan Bank untuk memenuhi kewajiban yang jatuh tempo dari sumber pendanaan arus kas, dan/atau dari aset likuid berkualitas tinggi yang dapat diagunkan, tanpa mengganggu aktivitas dan kondisi keuangan Bank. Risiko ini disebut juga Risiko likuiditas pendanaan (funding liquidity risk). Risiko Likuiditas juga dapat disebabkan oleh ketidakmampuan Bank melikuidasi aset tanpa terkena diskon yang material karena tidak adanya pasar aktif atau adanya gangguan pasar (market disruption) yang parah.

\section{4) Operational Risk.}

Risiko Operasional adalah Risiko akibat ketidakcukupan dan/atau tidak berfungsinya proses internal, kesalahan manusia, kegagalan sistem, dan/atau adanya kejadian eksternal yang 
mempengaruhi operasional Bank. Sumber Risiko Operasional dapat disebabkan antara lain oleh sumber daya manusia, proses, sistem, dan kejadian eksternal.

\section{5) Legal Risk.}

Risiko Hukum adalah Risiko yang timbul akibat tuntutan hukum dan/atau kelemahan aspek yuridis. Risiko ini juga dapat timbul antara lain karena keiadaan peraturan perundang-undangan yang mendasari atau kelemahan perikatan, seperti tidak dipenuhinya syarat sahnya kontrak atau agunan yang tidak memadai.

\section{6) Strategic Risk.}

Risiko Stratejik adalah Risiko akibat ketidaktepatan Bank dalam mengambil keputusan dan/atau pelaksanaan suatu keputusan stratejik serta kegagalan dalam mengantisipasi perubahan lingkungan bisnis. Sumber Risiko Stratejik antara lain ditimbulkan dari kelemahan dalam proses formulasi strategi dan ketidaktepatan dalam perumusan strategi, ketidaktepatan dalam implementasi strategi, dan kegagalan mengantisipasi perubahan lingkungan bisnis.

\section{7) Compliance Risk.}

Risiko Kepatuhan adalah Risiko yang timbul akibat Bank tidak mematuhi dan/atau tidak melaksanakan peraturan perundang-undangan dan ketentuan yang berlaku. Sumber Risiko Kepatuhan antara lain timbul karena kurangnya pemahaman atau kesadaran hukum terhadap ketentuan maupun standar bisnis yang berlaku umum.

\section{8) Reputational Risk.}

Risiko Reputasi adalah Risiko akibat menurunnya tingkat kepercayaan stakeholder yang bersumber dari persepsi negatif terhadap Bank. Salah satu pendekatan yang digunakan dalam mengkategorikan sumber Risiko Reputasi bersifat tidak langsung (below the line) dan bersifat langsung (above the line).

\section{9) Risiko Imbal Hasil}

Risiko imbal hasil timbul karena antara lain karena adanya perubahan perilaku nasabah dana pihak ketiga bank yang disebabkan oleh perubahan ekspektasi tingkat imbal hasil yang diterima dari bank. Perubahan ekspektasi bisa disebabkan oleh faktor internal seperti menurunnya nilai aset bank atau faktor eksternal seperti naiknya return imbal hasil yang ditawarkan bank lain.

10) Risiko Investasi. Risiko Investasi timbul akibat bank menanggung kerugian yang dialami nasabah yang melakukan pembiayaan pada bankbersangkutan. Sehingga hal tersebut akan mempengaruhi perilaku nasabah bank yang menempatkan dananya.

\section{F. Pengertian Tingkat Kesehatan Bank.}

Berdasarkan PBI No.13/I/PBI/2011, pada pasal 1 ayat (4): Tingkat Kesehatan Bank adalah hasil penilaian kondisi Bank yang dilakukan terhadap risiko dan kinerja Bank. Selanjutnya pada Pasal 2 ayat (1) Bank wajib memelihara dan/atau meningkatkan Tingkat Kesehatan Bank dengan menerapkan prinsip kehati-hatian dan manajemen risiko dalam melaksanakan kegiatan usaha. (2) Dalam rangka melaksanakan tanggung jawab atas 
kelangsungan usahaBank, Direksi dan Dewan Komisaris bertanggung jawabuntuk memelihara dan memantau Tingkat Kesehatan Bank serta mengambillangkah-langkah yang diperlukan untuk memelihara dan/atau meningkatkan Tingkat Kesehatan Bank sebagaimana dimaksud pada ayat (1). Dan ayat 3) Bank wajib melakukan penilaian tingkat kesehatan dengan menggunakan pendekatan risiko (Risk-based Bank Rating) baik secara individual maupun secara konsolidasi.

\section{G. Kerangka Konseptual.}

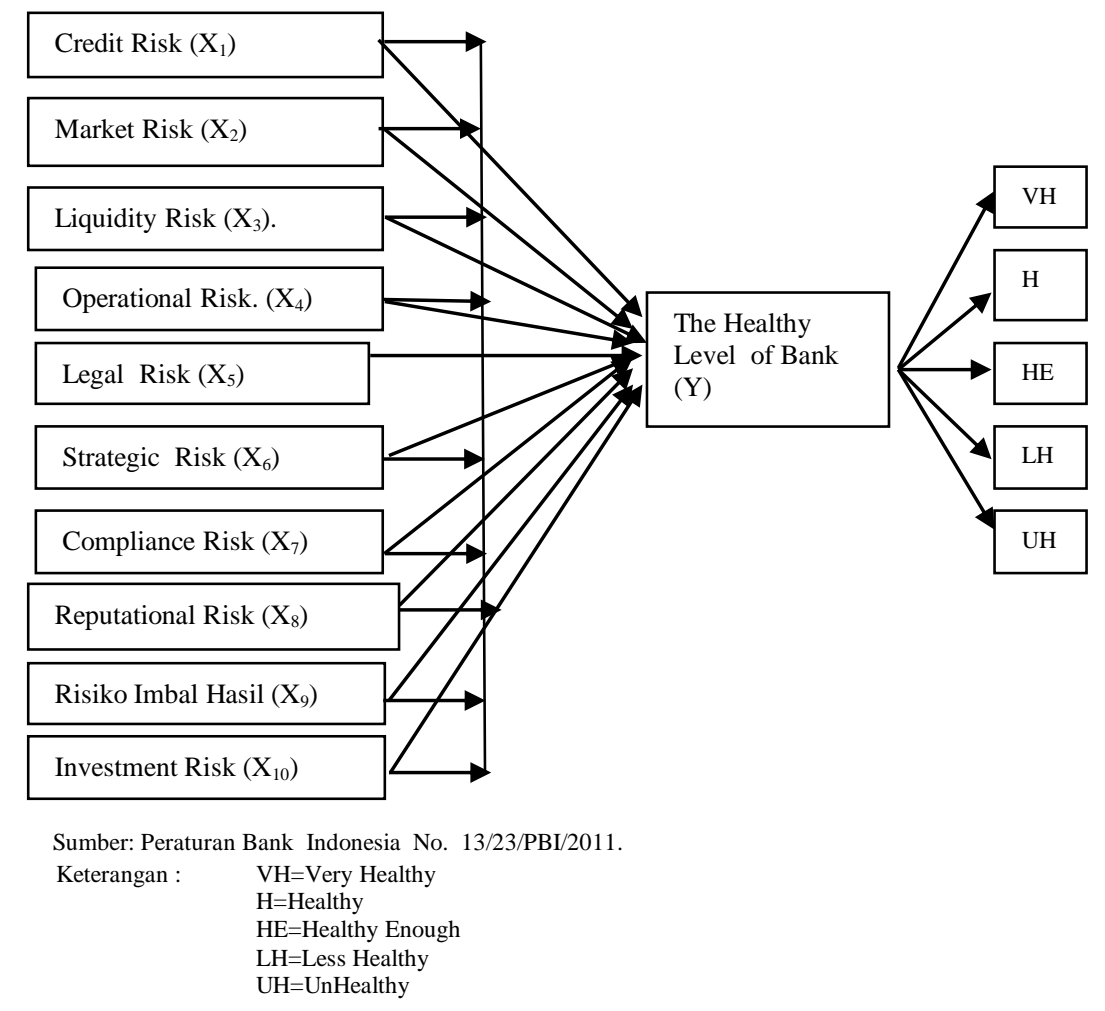

\section{H. Metode Penelitian.}

Populasi penelitian ini adalah Bank Umum Syariah yang ada di Indonesia. Pengambilan sample menggunakan metode Simple Random Sampling. Sampel yang dipilih untuk diteliti adalah PT Bank Muamalat, Tbk. Sumber data dalam penelitian ini berupa laporan tahunan yang dipublikasikan oleh Bank Muamalat,Tbk periode tahun 2014 sampai 2016.

\section{Analisa Risiko Profile.}

Risk Profile untuk bank syariah Pasal 7, Peraturan Otoritas Jasa Keuangan Nomor 8/POJK.03/2014 Tentang Penilaian Tingkat Kesehatan Bank Uumum Syariah Dan Unit Usaha Syariah menyatakan: (1) Penilaian terhadap faktor profil risiko sebagaimana dimaksud dalam Pasal 6 ayat (1) huruf a dan Pasal 6 ayat (2) merupakan penilaian terhadap risiko inheren dan kualitas penerapan manajemen risiko dalam operasional Bank yang dilakukan terhadap 10 (sepuluh) risiko yaitu:

1) Credit risk, 
2) Market risk,

3) Liquidity risk,

4) Operational risk,

5) Legal risk,

6) Strategic risk,

7) Complian risk,

8) Reputation risk.

9) Risiko imbal hasil; dan,

10) Risiko investasi.

Berikut ini adalah beberapa parameter/indikator minimum yang wajib dijadikan acuan oleh Bank dalam menilai Risiko inheren. Bank dapat menambah parameter/indikator lain yang relevan dengan karakteristik dan kompleksitas usaha Bank dengan memperhatikan prinsip proporsionalitas.

TABEL III. DEFINISI OPERASIONAL VARIABEL RISK PROFI BAGI BANK SYARIAH

\begin{tabular}{|c|c|c|c|}
\hline No & $\begin{array}{l}\text { Variabel } \\
\text { Penelitian }\end{array}$ & Definisi Operasional & Indikator \\
\hline 1. & Credit Risk $\left(\mathbf{X}_{1}\right)$ & $\begin{array}{l}\text { Risiko akibat kegagalan } \\
\text { debitur/dan/atau pihak lain dalam } \\
\text { memenuhi kewajiban kepada bank }\end{array}$ & $\begin{array}{l}\text {-Komposisi portofolio Aset } \\
\text {-Tingkat konsentrasi } \\
\text {-Kualitas penyediaan dana } \\
\text {-Kecukupan pendanaan } \\
\text {-Strategi penyediaan dana } \\
\text {-Sumber penyediaan dana } \\
\text {-Faktor Eksternal }\end{array}$ \\
\hline 2. & Market Risk $\left(\mathrm{X}_{2}\right)$ & $\begin{array}{l}\text { Risiko pada posisi neraca dan rekening } \\
\text { administratif termasuk transaksi } \\
\text { derivatif, akibat perubahan dan kondisi } \\
\text { pasar, termasuk risiko perubahan harga } \\
\text { option }\end{array}$ & $\begin{array}{l}\text {-Volume dan komposisi } \\
\text { portofolio } \\
\text {-Kerugian potensial } \\
\text {-Strategi dan kebijakan } \\
\text { bisnis }\end{array}$ \\
\hline 3. & $\begin{array}{l}\text { Liquidity Risk } \\
\left(\mathbf{X}_{3}\right)\end{array}$ & $\begin{array}{l}\text { Risiko akibat ketidakmampuan bank } \\
\text { untuk memenuhi kewajiban yang jatuh } \\
\text { tempo dari sumber pendanaan arus kas } \\
\text { dan/atau dari aset likuid berkualitas } \\
\text { tinggi yang dapat diagunkan, tanpa } \\
\text { mengganggu aktivitas dan kondisi } \\
\text { keuangan bank }\end{array}$ & $\begin{array}{l}\text {-Komposisi dari aset } \\
\text {-Transaksi rekening } \\
\text { administratif } \\
\text {-Konsentrasi aset dan } \\
\text { kewajiban } \\
\text {-Kerentanan pendanaan } \\
\text {-Akses sumber pendanaan }\end{array}$ \\
\hline 4. & $\begin{array}{l}\text { Operasional } \\
\text { Risk }\left(\mathrm{X}_{4}\right)\end{array}$ & $\begin{array}{l}\text { Risiko akibat ketidakcukupan dan/atau } \\
\text { tidak berfungsinya proses internal, } \\
\text { kesalahan manusia, kegagalan sistem } \\
\text { dan/ atau adanya kejadian eksternal } \\
\text { yang mempengaruhi operasional bank. }\end{array}$ & $\begin{array}{l}\text {-Karakteristik dan } \\
\text { kompleksitas bisnis } \\
\text {-SDM } \\
\text {-Teknologi informasi dan } \\
\text { infrastruktur } \\
\text {-Fraud internal dan } \\
\text { eksternal } \\
\text {-Kejadian eksternal }\end{array}$ \\
\hline 5. & Legal Risk $\left(\mathbf{X}_{5}\right)$ & $\begin{array}{l}\text { Risiko yang timbul akibat tuntutan } \\
\text { hukum dan/atau kelemahan aspek } \\
\text { yuridis, atau kejadian peraturan }\end{array}$ & $\begin{array}{l}\text {-Faktor legitasil } \\
\text {-Faktor kelemahan } \\
\text { perikatan }\end{array}$ \\
\hline
\end{tabular}




\section{Jurnal Ecobisma Vol 6 No. 1 Jan 2019}

\begin{tabular}{|c|c|c|c|}
\hline & & $\begin{array}{l}\text { perundang-undangan yang mendasari } \\
\text { atau kelemahan perikatan }\end{array}$ & $\begin{array}{l}\text {-Faktor } \\
\text { ketiadaan/perubaahan per } \\
\text { UU-ngan }\end{array}$ \\
\hline 6. & $\begin{array}{l}\text { Strategic Risk } \\
\left(\mathbf{X}_{6}\right)\end{array}$ & $\begin{array}{l}\text { Risiko akibat ketidaktepatan bank } \\
\text { dalam mengambil keputusan dan/atau } \\
\text { pelaksanaan suatu keputusan strategic } \\
\text { serta kegagalan dalam mengantisipasi } \\
\text { perubahan lingkungan bisnis }\end{array}$ & $\begin{array}{l}\text {-Kesesuaian startegi } \\
\text {-Risiko startegi } \\
\text {-Posisi bisnis bank } \\
\text {-Pencapaian rencana bisnis }\end{array}$ \\
\hline 7. & $\begin{array}{l}\text { Compliance Risk } \\
\left(\mathbf{X}_{7}\right)\end{array}$ & $\begin{array}{l}\text { Risiko yang timbul akibat bank tidak } \\
\text { mematuhi dan/atau tidak } \\
\text { melaksanakan peraturan per UU dan } \\
\text { ketentuan yang berlaku }\end{array}$ & $\begin{array}{l}\text {-Jenis pelanggaran } \\
\text {-Track record } \\
\text { ketidakpatuhan } \\
\text {-Pelanggaran standar bisnis }\end{array}$ \\
\hline 8. & $\begin{array}{l}\text { Reputational } \\
\text { Risk }\left(X_{8}\right)\end{array}$ & $\begin{array}{l}\text { Risiko akibat menurunnya tingkat } \\
\text { kepercayaan stakeholder yang } \\
\text { bersumber dari persepsi negative } \\
\text { terhadap bank }\end{array}$ & $\begin{array}{l}\text {-Pengaruh reputasi negative } \\
\text {-Pelanggaran etika bisnis } \\
\text {-Kompleksitas produk bank } \\
\text {-Materialitas } \\
\text {-Keluhan nasabah }\end{array}$ \\
\hline 9. & $\begin{array}{l}\text { Risiko Imbal } \\
\text { Hasil }\left(\mathbf{X}_{9}\right)\end{array}$ & $\begin{array}{l}\text { Resiko akibat perubahan tingkat } \\
\text { imbal hasil yang dibayarkan kepada } \\
\text { nasabah karena terjadi perubahan } \\
\text { tingkat imbal hasil yang diterima bank } \\
\text { dari penyaluran dana, yang dapat } \\
\text { memengaruhi perilaku nasabah dana } \\
\text { pihak ketiga bank }\end{array}$ & $\begin{array}{l}\text { - perubahan tingkat imbal } \\
\text { hasil } \\
\text { - perilaku nasabah dana } \\
\text { pihak ketiga } \\
\text { - faktor internal } \\
\text { - faktor eksternal }\end{array}$ \\
\hline 10. & $\begin{array}{l}\text { Investnent Risk } \\
\left(\mathbf{X}_{10}\right)\end{array}$ & $\begin{array}{l}\text { Resiko akibat bank ikut } \\
\text { menanggung kerugian usaha nasabah } \\
\text { yang dibiayai dalam pembiayaan } \\
\text { berbasis bagi hasil. }\end{array}$ & $\begin{array}{l}\text { - menanggung kerugian } \\
\text { usaha nasabah } \\
\text { - perjanjian pembagian } \\
\text { keuntungan dan kerugian } \\
\text { - Sifat investasi }\end{array}$ \\
\hline 11. & $\begin{array}{l}\text { Bank Health } \\
\text { Level }(Y)\end{array}$ & $\begin{array}{l}\text { Hasil penilaian kondisi Bank yang } \\
\text { dilakukan berdasarkan risiko termasuk } \\
\text { risiko terkait penerapan prinsip syariah } \\
\text { dan kinerja bank ( Risk-based Bank } \\
\text { Rating) }\end{array}$ & $\begin{array}{l}\text {-Sangat Sehat } \\
\text {-Sehat } \\
\text {-Cukup Sehat } \\
\text {-Kurang Sehat } \\
\text {-Tidak Sehat }\end{array}$ \\
\hline
\end{tabular}

\section{Pembahasan.}

Tingkat Kesehatan Bank Diti njau dari Aspek Risk Profile

1. Net Performing Financing (NPF).

Nilai Net Performing Financing Bank Muamalat Indonesia pada tahun 2014-2016 ternyata mengalami penurunan yaitu tahun 2014 sebesar 6,55\% (Cukup Sehat); tahun 2015 sebesar 7,11\% (Cukup Sehat); dan tahun 2016 sebesar 3,83\% ( Sehat). Hal ini menunjukkan bahwa NPF dalam keadaan semakin sehat artinya Bank Muamalat mampu mengurangi kredit bermasalah yang membuat bank mengalami keuntungan dari kredit tersebut.

\section{Financing to Debt Ratio (FDR).}


Nilai Financing to Debt Ratio Bank Muamalat Indonesia mengalami peningkatan pada tahun 2014-2016, yang dapat diketahui nilai FDRnya tahun 2014 sebesar 83,71\% (Sehat); tahun 2015 sebesar 90,30\% (Cukup Sehat); dan tahun 2016 sebesar 95,44\% (Cukup Sehat). Namun demikian, walaupun nilai yang dihasilkan meningkat artinya dapat dikatakan cukup sehat, akan tetapi hal ini menunjukkan penurunan kemampuan bank Muamalat Indonesia memenuhi kewajiban yang dihasilkan dari dna pihak ketiga.

\section{Daftar Pustaka:}

Analisis Penerapan Peraturan Bank Indonesia No. 13/1/PBI/2011 Terhadap Nilai Perusahaan

Bank Indonesia. 2004. Surat Edaran Bank Indonesia, No.6/23/DPNP:Tentang Sistem Penilaian Tingkat Kesehatan Bank Umum.

Bank Indonesia. 2011. Peraturan Bank Indonesia.No.13/1/PBI/2011:Tentang Penilaian Tingkat Kesehatan Bank Umum.

Baridwan, Zaki. 2008. Intermediate Accounting. Edisi 8. Yogyakarta: BPFE.

Bank Indonesia. 2013. Kodifikasi Peraturan Bank Indonesia Kelembagaan Penilaian Tingkat Kesehatan Bank.

Bank Indonesia, 2008, Surat Edaran Bank Indonesia Nomor 9/12/DPNP Tanggal 30 Mei 2008 Tentang Pelaksanaan Good Corporate Governance bagi Bank Umum.

Bank Indonesia, 2012, Peraturan Bank Indonesia Nomor 14/18/PBI/2012 Tentang Kewajiban Penyediaan Modal Minimum Bank Umum.

Bank Indonesia, Surat Edaran Bank Indonesia Nomor 15/15/DPNP tahun 2013, Tentang Pelaksanaan Good Corporate Governance bagi Bank Umum. Bruno, VG and Claessens, S 2004, 'Corporate Go-vernance and Regulation: Can There Be Too Much th of a Good Thing, The 6 Annual Darden Conference on Emerging Markets. Chitan, Gheorghe, 2012, 'Corporate Governance and Bank Performance in the Romanian Bank-ing Sector', Procedia Economics and Finance.

Economics, University of Gajah Mada. Circular Bank Indonesia (BI) No. 13/24 / DPNP Date October 25, 2011 on the Assessment of Commercial Banks [5]Kasmir, 2008, Banks and Other Financial Institutions. Revised Edition. Jakarta, PT. Raja Grafindo Persada.

Hasibuan, H.Malayu S.P. 2009. Dasar-dasar Perbankan. Jakarta: Bumi Aksara.

Hasibuan, H.Malayu S.P. 2009. Dasar-dasar Perbankan. Jakarta: Bumi Aksara.

Husnaini, Wahidatul, Susi Retna Cahyaningtyas and Rahmi Sri Ramadhani, 2014, 'Analisis Pro

fil Risiko Bank dengan Pendekatan Inheren Risk', Jurnal Aksioma, Vol. 13 No. 1, June pp. 20-33.

Juwenda, I Kt Galih Mitra, Susi Retna Cahyaning tyas and Wahidatul Husnaini, 2014, ‘

Kasmir. 2013. Dasar-dasar Perbankan. Jakarta: Rajawali Press.Bank Indonesia. 2015.

Kasmir, 2012, Analysis of Financial Statements. Jakarta, PT Persada Raja Grafindo. Indonesian Institute of Accountants (2009: 1), Law No. 10/1998. Jakarta on Banking Regulation of Bank Indonesia, 2011. Jakarta.

Latumaerissa, Julius R. 2014. Manajemen Bank Umum. Jakarta: Mitra Wacana Media.

Munawaroh. 2012. Panduan Memahami Metodologi Penelitian. Malang: Intimedia 
Nursatyani, Anisa, 2011, Analisis Pengaruh Efi-siensi Operasi, Risiko Kredit, Risiko Pasar, dan Modal Terhadap Kinerja Keuangan Perban-kan',Undergraduate Thesis, Fakultas Ekonomi Universitas Diponegoro.

Peni, Emilia \& Sami Vahamaa, 2011, Did Good Corporate Governance Improve Bank Performance During the Financial Crisis, Journal of Financial Services Research, pp. 130. Permatasari, Ika and Retno Novitasary, 2014, 'Pengaruh Implementasi Good Corporate Gover-nance terhadap Permodalan dan Kinerja Per-bankan di Indonesia: Manajemen Risiko Seba-gai Variabel Intervening', Jurnal Ekonomi Kuan-titatif Terapan, Vol 7 No. 1 February, pp. 52-59.

Perbankan', Simposium Nasional Akuntansi XVII Lombok.

Ratih, Ni Made Dwi Kumala, 2011, 'Pengaruh Risiko Kredit terhadap Nilai Perusahaan dengan Good Corporate Governance sebagai Variabel Pemoderasi',Fakultas Ekonomi Universitas Udayana.

Regulation of Financial Accounting Standards, 2012, Jakarta.

Simamora, Henry. 2003. Akuntansi: Basis Pengembalian Keputusan Bisnis. Jakarta: Salemba Empat.

SE BI Bank Indonesia. 2011. Surat Edaran Bank Indonesia Nomor:13/24/DPNP Tentang Penilaian Tingkat Kesehatan Bank Umum.

Saidi, N 2007, Linking Governance and Competi-tiveness, Oman Economic Association Conference Muscat, Oman March 24-25, 2007.

Suhartati, Titi, Sabar Warsini and Nedsal Sixpria, 2011, 'Pengaruh Pengungkapan Tanggung Ja wab Sosial dan Praktek Tata Kelola Perusahaan dengan Nilai Perusahaan',Jurnal Ekonomi dan Bisnis,Vol.10 No. 2 Desember 2011, pp. 95-105.

Tobin's, James,1969, ‘A General Equilibrium Ap-proach to Monetary Theory',Journal of Money,

Tri Hendro, Conny Tjandra Rahardja, 2014, Banks and Non-Bank Financial Institutions in Indonesia, Yogyakarta: UPP STIM YKPN.

Tjondro, David \& R Wilopo, 2011,'Pengaruh Good Corporate Governance terhadap Profitabilitas dan Kinerja Saham Perusahaan Perbankan yang Tercatat di Bursa Efek Indonesia', Journal of Business and Banking, Volume I, No. 1, pp. 1-14.

Undang-Undang Nomor 10 Tahun 1998 Tentang Perbankan.

Widyaningrum Hening Asih, Topowijono Suhadak, 2014, Analysis Health level of Bank Using Risk-Based Bank Rating (RBBR) Method, (Studies in Bank Listed in Indonesia Stock Exchange Composite Index Sub Banking Sector in 2012), Faculty of Administration, University of Brawijaya, Malang, Journal of Business Administration (JAB) Vol. 9 No. 2 April 2014. 